\section{Número da RBSO apresenta estudos em SST com diversidade regional e temas relevantes em Saúde do Trabalhador}

\author{
RBSO new issue brings OSH studies from different regions \\ unveiling relevant themes on workers' health
}

Após duas edições dedicadas a um dossiê temático sobre políticas públicas em Saúde do Trabalhador (ST), este número da RBSO publica uma coletânea de oito artigos, um relato de experiência, uma comunicação breve e uma resenha que trazem diferentes estudos no campo da ST.

Os trabalhos refletem uma salutar efervescência científica advinda de pós-graduações pelo Brasil afora e que atuam com interfaces em Saúde do Trabalhador. A frequência de submissão de artigos para a revista baseados em dissertações de mestrado e teses de doutorado vem aumentando, acompanhando o incremento da massa crítica na Academia ligada à Saúde do Trabalhador. Dos oito artigos aqui publicados, cinco são provenientes de dissertações de mestrado defendidas e um de uma pesquisa de doutorado em andamento.

Outro aspecto interessante é a diversidade geográfica da origem dos trabalhos: três são da Bahia, três de São Paulo, dois de Minas Gerais, um do Distrito Federal e um do Rio Grande do Sul, além de um proveniente de Portugal.

Embora tratem de diferentes temas, podem ser observadas similaridades entre alguns dos objetos de estudo.

Os dois artigos que abrem esta edição abordam o trabalho rural. Curiosamente, não tratam de intoxicações por agrotóxicos, tema recorrente em um grande número de artigos publicados por sua importância ocupacional e ambiental. Trazem importante contribuição ao abordar outros problemas relacionados à saúde do trabalhador agroflorestal, que, pelas características do trabalho, independentemente de ser exercido em grandes ou pequenas propriedades, não podem ser menosprezados. Simões e Rocha (p. 17-25) levantaram os agravos que deram origem ao absenteísmo-doença entre trabalhadores de uma grande empresa florestal em Minas Gerais analisando atestados médicos emitidos na empresa. As doenças do aparelho osteomuscular e as doenças do aparelho respiratório, foram as que mais geraram atestados e causaram absenteísmo. Meucci e colegas (p. 6-16) estudaram a prevalência da dor lombar na população de produtores de fumo no Rio Grande do Sul e descreveram o impacto desse agravo nas atividades que são exercidas por esses trabalhadores. Dificuldades econômicas e distúrbios psiquiátricos menores foram identificados como fatores de risco para limitação no trabalho por dor lombar no mês anterior à pesquisa. 
Lemos, Marqueze e Moreno (p. 26-34), estudando dor na coluna vertebral e lombar em motoristas de caminhão de uma empresa de transportes de carga de longa distância, também encontraram, entre outros resultados, fatores de saúde mental relacionados com a ocorrência de dor.

Na Bahia, Fonseca e Araújo (p. 35-49) estudaram dez grandes grupos de trabalhadores industriários de acordo com a Classificação Brasileira de Ocupações (CBO) para estimar a prevalência de transtornos mentais comuns (TMC). A prevalência de TMC entre os 41.639 trabalhadores foi de 11,6\%. Os trabalhadores de serviço administrativo e os técnicos de nível médio apresentaram, respectivamente, a maior $(13,2 \%)$ e a menor $(5,0 \%)$ prevalência de TMC nessa população formal de trabalhadores.

A violência no trabalho é outro tema comum a alguns dos trabalhos publicados. Em um estudo realizado em duas penitenciárias em um município do estado de São Paulo, Alves e Binder (p. 50-62) mostram a violência cotidiana a que estão sujeitos os que ali trabalham e agregam mais informações aos poucos estudos existentes sobre as condições de trabalho neste setor no Brasil. Destacam que as ameaças e as agressões físicas e verbais são referidas por $67,8 \%$ dos trabalhadores que participaram do estudo.

Dois outros estudos também abordam a relação entre violência e acidentes do trabalho. Lacerda, Fernandes e Nobre (p. 63-74) levantaram o perfil socioeconômico e ocupacional dos trabalhadores que vieram a óbito por acidentes de trabalho relacionados com a violência urbana. Feitosa e Fernandes (p. 75-85) avaliam como fonte alternativa de informações para estudar os casos de acidentes de trabalho fatais, os jornais impressos, que cotidianamente retratam a violência urbana, incluindo os óbitos que ocorrem no trabalho. Ambas as pesquisas foram realizadas na Bahia e chegam, por metodologias e fonte de dados diferentes, a um resultado semelhante: a violência urbana como um evento causal importante de acidentes de trabalho, mas negligenciado nos sistemas de informação tradicionais.

O estudo de Vasconcelos (p. 86-100), por sua vez, baseado em informações do sistema interno de registro das ações dos Auditores Fiscais do Trabalho, faz uma avaliação das ações de fiscalização do Ministério do Trabalho, em um período abrangente, no que concerne às normas de segurança e saúde no trabalho (SST). Os resultados apontam a necessidade de melhor definição de prioridades, baseadas em indicadores de morbimortalidade, e sugere melhorias organizacionais para promover uma fiscalização mais efetiva.

Ainda neste número, Lima e colegas (p. 101-110) nos oferecem um relato de experiência no qual descrevem uma perícia judicial coletiva de caso de assédio moral no setor bancário, com trabalhadores acometidos por LER/DORT. Oliveira, Cabral Pinto e Almeida Barros (p. 111-118), por sua vez, descrevem, em uma comunicação breve, os resultados de um estudo que procurou verificar a influência de participar em programas de formação profissional na auto-percepção de saúde mental de trabalhadores empregados e desempregados, em Portugal.

Completa esta edição, a resenha elaborada por Machado e Silveira (p. 119-121), sobre o livro de Smith e Leggat, que trata de tema tão relevante quanto delicado: o tabagismo entre trabalhadores da saúde.

Boa leitura! 